\title{
Determination of Mesalamine by Spectrofluorometry in Human Serum after Solid-Phase Extraction with Ni-Al Layered Double Hydroxide as a Nanosorbent
}

\author{
Hossein Abdolmohammad-Zadeh* and Solmaz, Kohansal \\ Department of Chemistry, Faculty of Sciences, Azarbaijan University of Tarbiat Moallem, \\ Tabriz-Marageh Road km 35, 53714-161 Tabriz, Iran
}

\begin{abstract}
Hidróxido duplo lamelar de níquel-alumínio nanoestruturado foi sintetizado e o potencial do material obtido, foi avaliado como sorvente para extração em fase sólida (SPE), na separação e pré-concentração de quantidades traço de mesalazina (ácido 5-aminossalicílico) usando o método de coluna. $\mathrm{O}$ analito retido em $\mathrm{Ni}$-Al LDH foi removido por solução de $\mathrm{NaOH}$ e a concentração de 5-ASA eluída foi então determinada espectrometricamente em $\lambda_{\text {em }}=480 \mathrm{~nm}$ com excitação em $\lambda_{\mathrm{ex}}=340 \mathrm{~nm}$. Vários parâmetros experimentais afetando a eficiência da extração de mesalazina em $\mathrm{Ni}-\mathrm{Al}\left(\mathrm{NO}_{3}^{-}\right) \mathrm{LDH}$, tais como $\mathrm{pH}$, quantidade de sorvente, taxa de fluxo da quantidade de amostra, condições de eluição e volume de amostra, foram investigados. Nas condições experimentais ideais, o limite de detecção e o fator de enriquecimento foram 0,04 e $40 \mu \mathrm{g} \mathrm{L} \mathrm{L}^{-1}$, respectivamente. A curva de calibração do sistema de pré-concentração foi linear no intervalo de $0,1-45,0 \mu \mathrm{g} \mathrm{L}^{-1} \mathrm{com}$ um coeficiente de correlação 0,998 . O desvio padrão relativo resultante da análise de seis repetições de soluções de $100 \mathrm{~mL}$ contendo $1,0 \mu \mathrm{g} \mathrm{L} \mathrm{L}^{-1}$ de mesalazina foi 2,05\%. O método otimizado foi aplicado com sucesso na determinação de mesalazina em amostras de soro de sangue.
\end{abstract}

Nanostructured nickel-aluminum layered double hydroxide (Ni-Al LDH) was synthesized and the potential of the obtained material, as solid-phase extraction (SPE) sorbent, for separation and pre-concentration of trace amount of mesalamine (5-aminosalicylic acid) was assessed using column method. The retained analyte on $\mathrm{Ni}-\mathrm{Al} \mathrm{LDH}$ was eluted with $\mathrm{NaOH}$ solution and the concentration of the elueted 5-ASA was then spectrofluorometrically determined at $\lambda_{\mathrm{em}}=480 \mathrm{~nm}$ with excitation at $\lambda_{\mathrm{ex}}=340 \mathrm{~nm}$. Various experimental parameters affecting the extraction efficiency of mesalamine on $\mathrm{Ni}-\mathrm{Al}\left(\mathrm{NO}_{3}^{-}\right) \mathrm{LDH}$, such as $\mathrm{pH}$, amount of sorbent, sample loading flow rate, elution conditions and sample volume, were investigated. In the optimum experimental conditions, the limit of detection and enrichment factor were 0.04 and $40 \mu \mathrm{g} \mathrm{L}^{-1}$, respectively. The calibration graph for the pre-concentration system was linear in the range of $0.1-45.0 \mu \mathrm{g} \mathrm{L}{ }^{-1}$ with a correlation coefficient of 0.998 . The relative standard deviation (RSD) resulting from the analysis of six replicates of $100 \mathrm{~mL}$ solutions containing $1.0 \mu \mathrm{g} \mathrm{L}^{-1}$ mesalamine was $2.05 \%$. The optimized method was successfully applied to the determination of mesalamine in blood serum samples.

Keywords: nickel-aluminum layered double hydroxide, nanosorbent, solid phase extraction, mesalamine, spectrofluorometry, human blood serum

\section{Introduction}

Mesalamine (mesalazine), chemically known as 5-aminosalicylic acid (5-ASA), is an important non-steroidanti-inflammatory drug (NSAID) used in the treatment of Crohn's disease and ulcerative colitis, which may provide protection against the development of colorectal cancer in patients suffering from inflammatory bowel diseases (IBD). ${ }^{1}$ A number of analytical methods has been developed

*e-mail: h.abdol@azaruniv.edu for the analysis of mesalamine in pharmaceutical dosage forms and biological matrices. These methods include voltammetry, ${ }^{2-4}$ spectrophotometry, ${ }^{5,6}$ spectrofluorometry ${ }^{7,8}$ coulometery, ${ }^{9}$ and high-performance liquid chromatography (HPLC) combined with UV, ${ }^{10-12}$ fluorescence, ${ }^{13,14}$ mass spectrometry (MS), ${ }^{15,16}$ and electrochemical (EC) ${ }^{17}$ detections. Mesalamine is usually present at trace levels in a complex biological matrix, and the potentially interfering endogenous substances (which are usually present at higher concentrations than the drug) need to be removed before the analysis. Moreover, due to the presence of the 
primary aromatic amino group $\left(-\mathrm{NH}_{3}{ }^{+} \mathrm{pKa}=6\right)$, carboxylic group $(-\mathrm{COOH} \mathrm{pa}=3)$ and phenolic group $(-\mathrm{OH} \mathrm{pKa}=$ 13.9) in the molecule, ${ }^{18}$ mesalamine exhibits amphoteric properties, which (together with its high polarity) complicate its separation and detection. ${ }^{10}$ In order to remove the interfering contribution from the biomatrices and to increase the selectivity and sensitivity of the analytical method, a sample preparation step is necessary prior to the instrumental analysis of mesalamine.

Solid phase extraction (SPE) is one of the most important pre-concentration methods because of its simplicity, flexibility to choose the solid phase, high pre-concentration factor, low consumption of the organic solvents, low cost and short extraction time for sample preparation. In SPE procedures, the choice of the sorbent is a key point because it can control the analytical parameters such as selectivity, sensitivity, affinity, and capacity. The type and amount of the sorbent required depend on the chemical nature and concentration of the drug, the sample type and the nature of any interfering substances. ${ }^{19,20}$

Layered double hydroxides (LDHs) are a class of synthetic two dimensional nanostructured inorganic materials. These materials have positively charged layers of metal hydroxides, between which are located anions and, in general, some water molecules. The general formula of LDHs can be represented by $\left[\mathrm{M}_{1-\mathrm{x}}^{2+} \mathrm{M}_{\mathrm{x}}^{3+}(\mathrm{OH})_{2}\right]^{\mathrm{x}+}\left[\mathrm{A}_{\mathrm{x} / \mathrm{n}}^{\mathrm{n}-} \cdot \mathrm{mH}_{2} \mathrm{O}\right]^{\mathrm{x}-}$, where $\mathrm{M}^{2+}$ is a divalent cation (such as $\mathrm{Mg}^{2+}, \mathrm{Ni}^{2+}, \mathrm{Ca}^{2+}$, $\mathrm{Cu}^{2+}, \mathrm{Mn}^{2+}, \mathrm{Co}^{2+}$ or $\mathrm{Zn}^{2+}$ ), $\mathrm{M}^{3+}$ is a trivalent cation (such as $\mathrm{Al}^{3+}, \mathrm{Cr}^{3+}, \mathrm{Ga}^{3+}$ or $\mathrm{Fe}^{3+}$ ), $\mathrm{A}^{\mathrm{n}-}$ is an interlayer anion (such as $\mathrm{CO}_{3}^{2-}, \mathrm{SO}_{4}^{2-}, \mathrm{Cl}^{-}, \mathrm{NO}_{3}^{-}$), $\mathrm{x}$ value is equal to the molar ratio $\mathrm{M}^{3+} /\left(\mathrm{M}^{2+}+\mathrm{M}^{3+}\right)$ and $\mathrm{m}$ is the number of water molecules located in the interlayer region together with anions..$^{21-23}$ The electrostatic interactions and hydrogen bonds between layers and contents of the gallery hold the layers together, forming a three dimensional structure. Due to their large surface area and high anion exchange capacity, LDHs can be presented as novel and suitable nanosorbents for solid-phase extraction of acidic drugs in complex matrices, as well as their other applications in catalysis, polymer additives, modified electrodes, photochemistry, etc. ${ }^{24-29}$

The aim of the present work is to introduce a novel nanosorbent for the solid-phase extraction and the preconcentration of trace amount of mesalamine in complex matrices. For this purpose, nickel-aluminum layered double hydroxide $\left(\mathrm{Ni}-\mathrm{Al}\left(\mathrm{NO}_{3}^{-}\right) \mathrm{LDH}\right)$ was synthesized and structurally and morphologically characterized by $\mathrm{X}$-ray diffractometry (XRD), Fourier transform infrared spectroscopy (FTIR) and scanning electron microscopy (SEM). The potential of $\mathrm{Ni}-\mathrm{Al}\left(\mathrm{NO}_{3}^{-}\right) \mathrm{LDH}$ for the preconcentration of trace mesalamine was assessed using column method. The extraction of mesalamine is based on the adsorption of its anion (5-aminosalicylate) on $\mathrm{Ni}-\mathrm{Al}\left(\mathrm{NO}_{3}^{-}\right) \mathrm{LDH}$ and/or its exchanging with $\mathrm{LDH}$ interlayer ions $\left(\mathrm{NO}_{3}^{-}\right)$. The stripping of the retained analyte was carried out by $3 \mathrm{~mol} \mathrm{~L}^{-1} \mathrm{NaOH}$ solution and the absorption of the pre-concentrated solution of 5 -aminosalicylate was determined by spectrofluorometry at $\lambda_{\mathrm{em}}=480 \mathrm{~nm}$ with excitation at $\lambda_{\mathrm{ex}}=340 \mathrm{~nm}$. The effects of various experimental parameters on the extraction efficiency were investigated and optimized. To evaluate the applicability of the proposed method, it was then applied to the determination of mesalamine in blood serum samples.

\section{Experimental}

\section{Apparatus and instruments}

Fluorescence spectra and intensity measurements were carried out using a FP-6200 spectrofluorometer (JASCO Co., Tokyo, Japan) with a wavelength range of 220-730 nm (with $1 \mathrm{~nm}$ intervals) for excitation and emission. The instrument is equipped with a $150 \mathrm{~W}$ xenon lamp, $1.0 \mathrm{~cm}$ quartz cell, dual monochromaters (silicon photodiode for excitation and photomultiplier for emission), Peltier thermostatted single cell holder (model ETC-272) and supported with PC-based Windows ${ }^{\circledR}$ Spectra Manager $^{\mathrm{TM}}$ software for JASCO Co. version 1.02. The slit widths for both excitation and emission were set at $5 \mathrm{~nm}$ and the fluorescence spectra were recorded at a scan rate of $1000 \mathrm{~nm} \mathrm{~min}^{-1}$. All measurements were performed under controlled temperature by Peltier thermostatted at $25{ }^{\circ} \mathrm{C}$. Fluorescence intensities were measured at $480 \mathrm{~nm}$ with excitation at $340 \mathrm{~nm}$ at $25^{\circ} \mathrm{C}$. A $2 \mathrm{~mL}$ polypropylene cartridge ( $30 \mathrm{~mm} \times 7 \mathrm{~mm}$ i.d.) (Shafa Co., Iran) packed with $0.2 \mathrm{~g}$ of nickel-aluminum LDH and fitted with small cotton beads at both ends to prevent material losses was used to pre-concentrate the analytes in SPE procedures. The flow rate of solution through the column was controlled with an air-driven fluid pump model P34112 (Taiwan).

In order to get structural information of the $\mathrm{LDH}$, XRD measurements were performed on a Bruker AXS (D8 Advance) $\mathrm{X}$-ray powder diffractometer $\left(\mathrm{Cu} \mathrm{K} \mathrm{K}_{\alpha}\right.$ radiation source, $\lambda=0.154056 \mathrm{~nm}$ ) between 5 and $65^{\circ}$, generated at $40 \mathrm{kV}$ and $35 \mathrm{~mA}$ at room temperature. In addition, FTIR spectra (4000-400 $\mathrm{cm}^{-1}$ ) were recorded on a Vector 22 (Bruker, Germany) Fourier transform infrared spectrometer using the $\mathrm{KBr}$ disk method with a ratio sample/KBr of $1: 100$ by mass. A scanning electron microscope (SEM), model P Scan Vega 2 (Czech Republic), was additionally used to examine the morphological characteristics of the sorbent. Samples for elemental analysis were prepared by dissolving 
$50 \mathrm{mg}$ of $\mathrm{LDH}$ with few drops of concentrated $\mathrm{HNO}_{3}$ and diluting to $50 \mathrm{~mL}$ with deionized water, and $\mathrm{Ni}$ and $\mathrm{Al}$ analysis were performed by flame atomic absorption spectrometry (FAAS) with a Varian SpectrAA 220 (Mulgrave, Victoria, Australia) instrument. The $\mathrm{pH}$ values were measured with a Metrohm pH-meter (model 827, Switzerland), supplied with a glass-combined electrode. An electronic analytical balance (Mettler Toledo, PB303, Switzerland) was used for weighting the solid materials. The validity of the presented method was checked by applying a spectrophotometric method. For this purpose, the concentration of the eluted analyte from the SPE column was spectrophotometrically measured at $325 \mathrm{~nm}^{10}$ using a UV-Vis T80 spectrophotometer (PG Instruments Ltd., England) with a wavelength range of 190-900 nm. The instrument is equipped with dual source lamp (tungsten and deuterium for visible and UV range, respectively), $1.0 \mathrm{~cm}$ quartz cell and PMT detector. The spectral bandwidth and response time were set at $2 \mathrm{~nm}$ and $0.2 \mathrm{~s}$, respectively.

\section{Standard solutions and reagents}

All chemicals used were of analytical-reagent grade and all solutions were prepared with doubly distilled deionized water (Shahid Ghazi Co, Tabriz, Iran). A $1000 \mathrm{mg} \mathrm{L}^{-1}$ stock solution of mesalamine (Fluka) was prepared by dissolving appropriate amount of reagent in deionized water, and stored at $4^{\circ} \mathrm{C}$ after preparation. Working standard solutions were daily obtained by suitable stepwise dilution of the stock solutions with deionized water and shaking them just prior to use. All salts and compounds used for the interference study, $\mathrm{NaOH}, \mathrm{HCl}(37 \%)$ and $\mathrm{LDH}$ precursors [i.e., purified nickel nitrate hexahydrate $\left(\mathrm{Ni}\left(\mathrm{NO}_{3}\right)_{2} \cdot 6 \mathrm{H}_{2} \mathrm{O}\right.$, $99 \%)$ and aluminum nitrate nonahydrate $\left(\mathrm{Al}\left(\mathrm{NO}_{3}\right)_{3} \cdot 9 \mathrm{H}_{2} \mathrm{O}\right.$, 99\%)] were purchased from Merck (Darmstadt, Germany). The $\mathrm{pH}$ adjustments were performed with $\mathrm{HNO}_{3}$ and $\mathrm{NaOH}$ (0.01-2.0 $\left.\mathrm{mol} \mathrm{L}^{-1}\right)$ solutions. The pipettes and vessels used for the trace analysis were kept in 15\% (v/v) nitric acid at least overnight and subsequently washed three times with deionized water prior to use.

\section{Preparation of nickel-aluminum layered double hydroxide}

$\mathrm{Ni}-\mathrm{Al}\left(\mathrm{NO}_{3}^{-}\right) \mathrm{LDH}$ was prepared by co-precipitation method with controlled $\mathrm{pH}$, followed by hydrothermal treatment as described elsewhere. ${ }^{30,31}$ The synthesis was carried out under $\mathrm{N}_{2}$ atmosphere, and all solutions were prepared using deionized water to avoid contamination. In the present work, the $\mathrm{Ni}^{2+}: \mathrm{Al}^{3+}$ molar ratio chosen for the synthesis of the LDH precursors was 2:1 to obtain stable layered compounds. For this purpose, $0.581 \mathrm{~g}$
$\mathrm{Ni}\left(\mathrm{NO}_{3}\right)_{2} \cdot 6 \mathrm{H}_{2} \mathrm{O}$ and $0.375 \mathrm{~g} \mathrm{Al}\left(\mathrm{NO}_{3}\right)_{3} \cdot 9 \mathrm{H}_{2} \mathrm{O}$ were added into $30 \mathrm{~mL}$ deionized water under vigorous stirring at room temperature. The $\mathrm{pH}$ of the reaction mixture was adjusted to 9.6 by the addition of $2 \mathrm{~mol} \mathrm{~L}^{-1} \mathrm{NaOH}$ solution. Then, the obtained slurry was subjected to hydrothermal treatment at a constant temperature of $100^{\circ} \mathrm{C}$ for about $24 \mathrm{~h}$. Afterward, the resulting precipitate was separated by centrifugation at $4000 \mathrm{rpm}$ for $10 \mathrm{~min}$, then washed three times with deionized water and dried at $60{ }^{\circ} \mathrm{C}$ for $6 \mathrm{~h}$.

\section{Column preparation}

$\mathrm{Ni}-\mathrm{Al}\left(\mathrm{NO}_{3}^{-}\right) \mathrm{LDH}$ was employed to create the solidphase extraction column as follows: the column was prepared by introducing $200 \mathrm{mg}$ of $\mathrm{Ni}-\mathrm{Al}\left(\mathrm{NO}_{3}^{-}\right) \mathrm{LDH}$ into an empty $2 \mathrm{~mL}$ polypropylene cartridge using the dry packing method. Small portion of cotton was placed on both ends of the column. Before loading the sample, $2 \mathrm{~mL}$ of $3 \mathrm{~mol} \mathrm{~L}^{-1} \mathrm{NaOH}$ solution were passed through the column to clean it. Then, the column was conditioned by passing only $3 \mathrm{~mL}$ of deionized water through it prior to each use. After loading, the retained analyte in the column was eluted with a $2.5 \mathrm{~mL}$ of $3 \mathrm{~mol} \mathrm{~L}^{-1} \mathrm{NaOH}$ as a desorbing and/or ion-exchanger solution.

\section{Sample preparation}

Human blood samples were obtained from healthy subjects who were not taking any drugs containing mesalamine. Whole blood was allowed to coagulate before separating the serum by centrifugation at $4000 \mathrm{rpm}$ for $15 \mathrm{~min}$. Then, a $100 \mu \mathrm{L}$ portion of serum was directly transferred into a $100.0 \mathrm{~mL}$ volumetric flask and after dilution to the mark with the deionized water, the concentration of mesalamine was determined as described in the following section.

\section{General procedure}

For the solid phase extraction and the pre-concentration of mesalamine, a $100.0 \mathrm{~mL}$ portion of aqueous standard or sample solution containing mesalamine in the range of 0.1-45.0 $\mu \mathrm{g} \mathrm{L}^{-1}(\mathrm{pH}$ 5) was passed through the $\mathrm{Ni}-\mathrm{Al}\left(\mathrm{NO}_{3}^{-}\right) \mathrm{LDH}$ nanosorbent in a micro-column at a flow rate of $2.0 \mathrm{~mL} \mathrm{~min}{ }^{-1}$. The $\mathrm{pH}$ of the solution was adjusted using minimum volume of $0.01 \mathrm{~mol} \mathrm{~L}^{-1} \mathrm{HNO}_{3}$ and/or $\mathrm{NaOH}$. The total volume added for $\mathrm{pH}$ adjustment never exceeded $1 \%$ of the total volume. The use of buffer was avoided to restrict the addition of foreign anions, which may adversely affect the 5-aminocalicylate ion adsorption. After loading, the retained analyte on the micro-column was 
eluted with $2.5 \mathrm{~mL}$ of $3 \mathrm{~mol} \mathrm{~L}^{-1} \mathrm{NaOH}$ solution at an elution rate of $1.0 \mathrm{~mL} \mathrm{~min}^{-1}$, and the mesalamine concentration in the eluted solution was spectrofluorometrically determined at $\lambda_{\mathrm{em}}=480 \mathrm{~nm}$ with excitation at $\lambda_{\mathrm{ex}}=340 \mathrm{~nm}$. A blank solution was also run under the same conditions without adding the analyte. The column could be repeatedly used after regeneration with $3 \mathrm{~mol} \mathrm{~L}^{-1} \mathrm{NaOH}$ solution and deionized water, respectively.

\section{Results and Discussion}

\section{Characterization of nanosorbent $\left(\mathrm{Ni}-\mathrm{Al}\left(\mathrm{NO}_{3}^{-}\right) \mathrm{LDH}\right)$}

$\mathrm{X}$-ray powder diffraction (XRD) is a very powerful technique for characterizing the structure of materials. Figure 1 shows XRD pattern of $\mathrm{Ni}-\mathrm{Al}\left(\mathrm{NO}_{3}^{-}\right) \mathrm{LDH}$. It can be observed the characteristic reflections of [l $\left.\begin{array}{lll}0 & 0 & 3\end{array}\right]$,

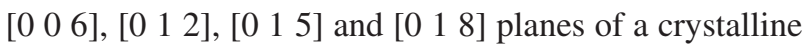
LDH. In the zone close to $2 \theta=60-62^{\circ}$, the typical doublet of [ [ $\left.\begin{array}{lll}1 & 1 & 0\end{array}\right]-\left[\begin{array}{lll}1 & 1 & 3\end{array}\right]$ planes of LDH was also observed. It can be seen that $\mathrm{Ni}-\mathrm{Al}\left(\mathrm{NO}_{3}^{-}\right) \mathrm{LDH}$ exhibits the characteristic reflections of hydrotalcite-like LDH and no other crystalline phase was present, being in agreement with results reported by other researchers. ${ }^{32}$

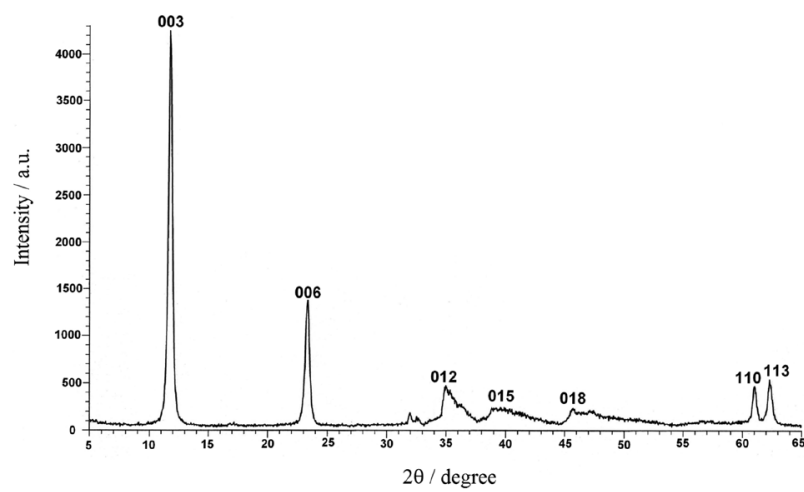

Figure 1. XRD pattern of $\mathrm{Ni}-\mathrm{Al}\left(\mathrm{NO}_{3}^{-}\right) \mathrm{LDH}$.

FTIR spectroscopy is another useful tool for the characterization of LDHs, involving the vibrations in the octahedral lattice, hydroxyl groups and interlayer anions. The absorption band $c a .3423 \mathrm{~cm}^{-1}$ in the FTIR spectrum of $\mathrm{Ni}-\mathrm{Al}\left(\mathrm{NO}_{3}^{-}\right) \mathrm{LDH}$ (Figure 2) can be assigned to the stretching vibration of the hydroxyl groups of $\mathrm{LDH}$ layers and interlayer water molecules. The bending mode of water molecules is responsible for the weak band at $1634 \mathrm{~cm}^{-1}$. The band with maximum peak at $1384 \mathrm{~cm}^{-1}$ is from the stretching vibration of $\mathrm{NO}_{3}{ }^{-}$ions intercalated in the interlayer gallery. Finally, the bands at $805,563 \mathrm{~cm}^{-1}$ and $432 \mathrm{~cm}^{-1}$ can be ascribed to $\mathrm{M}-\mathrm{O}$ stretching modes and $\mathrm{M}-\mathrm{O}-\mathrm{H}$ bending vibrations.

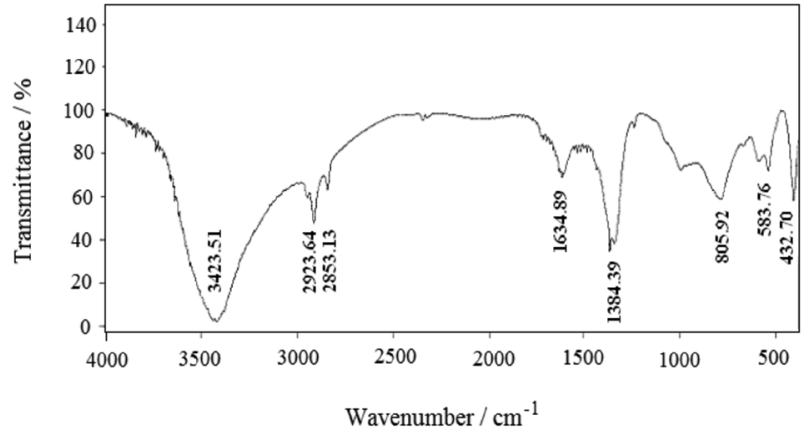

Figure 2. FTIR spectrum of $\mathrm{Ni}-\mathrm{Al}\left(\mathrm{NO}_{3}^{-}\right) \mathrm{LDH}$.

Scanning electron microscopy (SEM) was employed to explore the morphology of the nanosorbent. SEM image of Ni-Al $\left(\mathrm{NO}_{3}^{-}\right) \mathrm{LDH}$ (Figure 3 ) shows an aggregate that consists of crystallites, with a size of tens of nanometers, that were collected as small pseudo-spherical platelets after hydrothermally treated at $100{ }^{\circ} \mathrm{C}$ for about $24 \mathrm{~h}$. Microphotography clearly evidences the nanostructural strains, which leads to non-rigid platelet shape.

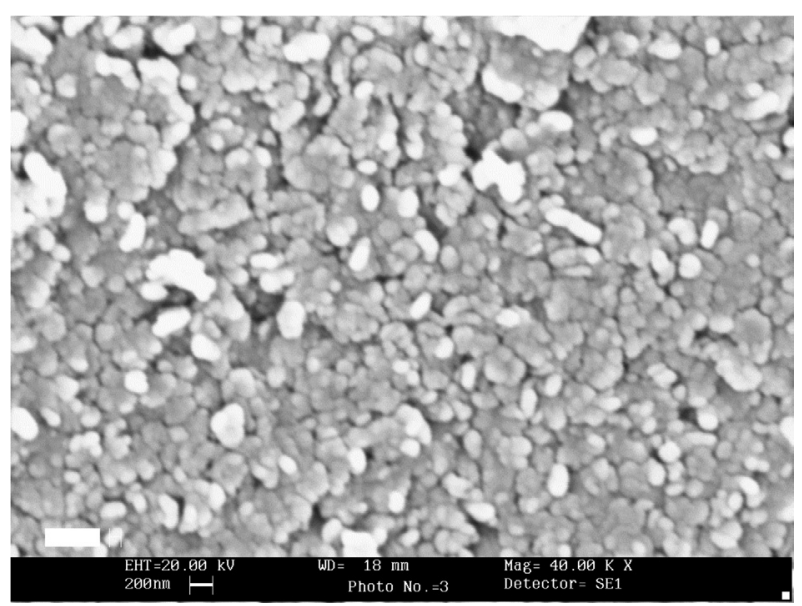

Figure 3. SEM image of $\mathrm{Ni}-\mathrm{Al}\left(\mathrm{NO}_{3}^{-}\right) \mathrm{LDH}$.

For chemical composition, $50 \mathrm{mg}$ of LDH were dissolved with few drops of concentrated $\mathrm{HNO}_{3}$ and diluted to $50 \mathrm{~mL}$ with deionized water. The amounts of $\mathrm{Ni}$ and $\mathrm{Al}$ in the obtained solution were then determined by FAAS. Results showed a Ni/Al molar ratio of 1.96. This value is approximately equal to the ratio used for preparing the starting solution $(\mathrm{Ni} / \mathrm{Al}=2)$, thus the synthesis process was efficient.

\section{Optimization of SPE conditions}

In order to optimize the sorption conditions for the retention of the mesalamine on $\mathrm{Ni}-\mathrm{Al}\left(\mathrm{NO}_{3}^{-}\right) \mathrm{LDH}$, several experimental variables affecting the extraction efficiency such as $\mathrm{pH}$, amount of LDH, sample loading flow rate, type, 
volume and concentration of eluent reagent, and sample volume were investigated. A $10.0 \mu \mathrm{g} \mathrm{L}^{-1}$ of mesalamine solution was used for all the measurements and in the impact parameters optimization procedure, the limits marked on the figures were obtained from three independent experiments that repeated under the same conditions.

\section{$\mathrm{pH}$ effect}

The $\mathrm{pH}$ effect on the extraction efficiency of mesalamine was studied. For this purpose, the $\mathrm{pH}$ values of sample solution were adjusted to a range of 2.0-12.0 with minimum volume of $0.01 \mathrm{~mol} \mathrm{~L}^{-1} \mathrm{HNO}_{3}$ and/or $\mathrm{NaOH}$. The recovery was calculated based on a difference between the amounts of the mesalamine in the starting sample and the solution that was eluted from the column. The obtained results are shown in Figure 4. It can be seen that at pH between 2 and 4, the extraction efficiency was low probably due to the dissolution of the LDH and the also impossible ion exchanging of mesalamine with LDH interlayer ions in strong acidic medium. The highest extraction efficiency was achieved between $\mathrm{pH} 4$ and 9. An increase in the concentration of the competing $\mathrm{OH}^{-}$anions at $\mathrm{pH}$ above 9.0 might be responsible for the observed decrease in the adsorption capacity at higher $\mathrm{pH}$. Therefore, $\mathrm{pH} 5$ was selected as the working $\mathrm{pH}$ in order to prevent the proteolysis of other organic compounds, which might exist in biological samples. On the other hand, it was not used any buffer solution because these may affect the adsorption of mesalamine due to the competition of the anionic species for the active sites of the nanosorbent.

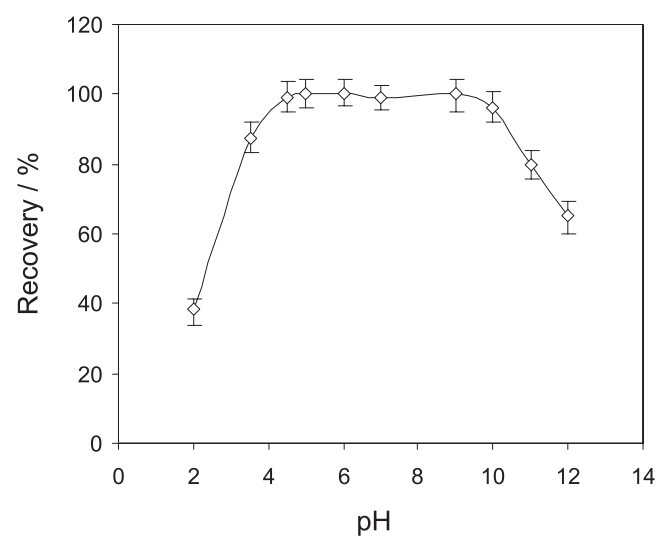

Figure 4. $\mathrm{pH}$ effect upon the retention of mesalamine on the $\mathrm{Ni}-\mathrm{Al}\left(\mathrm{NO}_{3}^{-}\right)$ LDH nanosorbent. Utilized conditions: mesalamine concentration of $10.0 \mu \mathrm{g} \mathrm{L} \mathrm{L}^{-1}$, nanosorbent amount of $200 \mathrm{mg}$, sample volume of $50 \mathrm{~mL}$

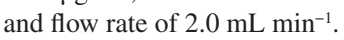

\section{Effect of flow rate of sample loading}

Flow rate of sample loading through the packed column is a very important parameter in this kind of study. This is because the flow rate not only affects the retention of analyte on the sorbent but also controls the frequency of analysis. The influence of mesalamine retention on nanometer-sized $\mathrm{Ni}-\mathrm{Al}\left(\mathrm{NO}_{3}^{-}\right) \mathrm{LDH}$ was investigated by varying the flow rate of the sample solution in the range of $0.5-5.0 \mathrm{~mL} \mathrm{~min}^{-1}$. It was found that the flow rate in the range of $0.5-3.0 \mathrm{~mL} \mathrm{~min}^{-1}$ had no significant effect on the recoveries of mesalamine according to the procedure of column experiments. However, at flow rates higher than $3.0 \mathrm{~mL} \mathrm{~min}^{-1}$, the recovery of mesalamine was reduced. Hence, for further experiments, the value of $2.0 \mathrm{~mL} \mathrm{~min}^{-1}$ was chosen as the sample flow rate.

\section{Optimization of elution conditions}

The conditions of eluting agents are vital for the extraction efficiency. Therefore, the choice of elution reagent and its optimum conditions should be carefully taken into account. For this reason, various desorbing reagents such as $\mathrm{NaOH}, \mathrm{NaCl}$ and $\mathrm{Na}_{2} \mathrm{CO}_{3}$ were tested to find the best stripping solution for the retained mesalamine. Among these, $\mathrm{NaOH}$ solution provided higher recovery. The concentration, volume, and flow rate of the $\mathrm{NaOH}$ solution were also optimized. For this purpose, various concentrations (1.0-5.0 $\mathrm{mol} \mathrm{L}^{-1}$ ) of $\mathrm{NaOH}$ were studied for the elution of retained analytes from the column. As can be seen in Figure 5, the concentration of $3.0 \mathrm{~mol} \mathrm{~L}^{-1} \mathrm{NaOH}$ was sufficient for the complete elution of the retained mesalamine from the column. By keeping the eluent concentration of $3.0 \mathrm{~mol} \mathrm{~L}^{-1} \mathrm{NaOH}$, the effect of elution volume $(1.0-5.0 \mathrm{~mL})$ on the recovery was investigated according to the procedure of column experiments. The results showed that $2.5 \mathrm{~mL}$ of $3.0 \mathrm{~mol} \mathrm{~L}^{-1} \mathrm{NaOH}$ solution at a flow rate of $1.0 \mathrm{~mL} \mathrm{~min}^{-1}$ was sufficient for complete elution of mesalamine (Figure 6).

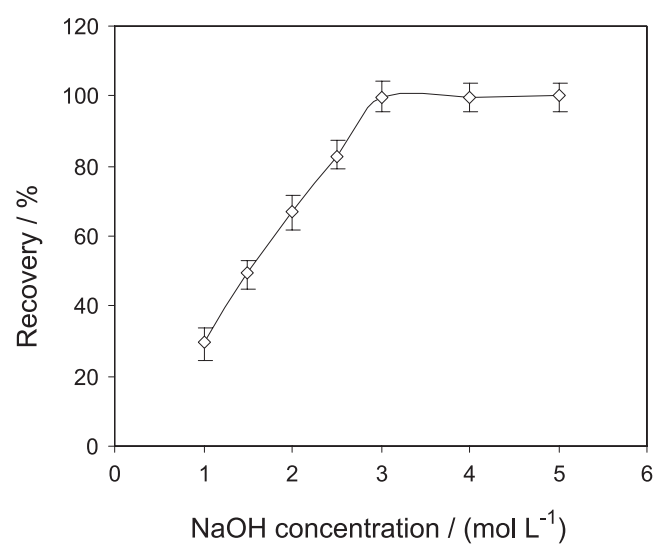

Figure 5. Effect of $\mathrm{NaOH}$ concentration on the elution of mesalamine from the $\mathrm{Ni}-\mathrm{Al}\left(\mathrm{NO}_{3}^{-}\right) \mathrm{LDH}$ nanosorbent. Utilized conditions: mesalamine concentration of $10.0 \mu \mathrm{g} \mathrm{L} \mathrm{L}^{-1}$, nanosorbent amount of $200 \mathrm{mg}$, sample volume of $50 \mathrm{~mL}, \mathrm{pH} 5$, flow rate of $2.0 \mathrm{~mL} \mathrm{~min}^{-1}$ and eluent volume of $3 \mathrm{~mL}$. 


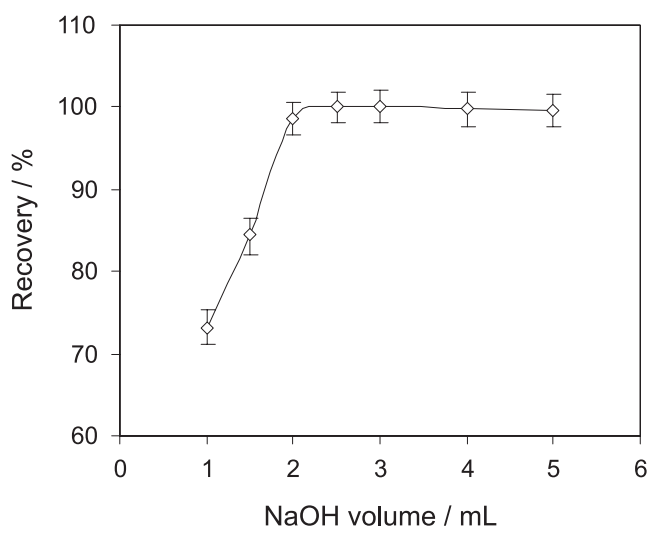

Figure 6. Effect of $\mathrm{NaOH}$ volume on the elution of mesalamine from the Ni-Al $\left(\mathrm{NO}_{3}^{-}\right) \mathrm{LDH}$ nanosorbent. Utilized conditions: mesalamine concentration of $10.0 \mu \mathrm{g} \mathrm{L}^{-1}$, nanosorbent amount of $200 \mathrm{mg}$, sample volume of $50 \mathrm{~mL}, \mathrm{pH} 5$, flow rate of $2.0 \mathrm{~mL} \mathrm{~min}^{-1}$ and $\mathrm{NaOH}$ concentration of $3 \mathrm{~mol} \mathrm{~L}^{-1}$.

\section{Effect of amount of nanosorbent}

The influence of Ni-Al $\left(\mathrm{NO}_{3}^{-}\right) \mathrm{LDH}$ amount on the recovery was also studied. For this aim, the extraction was conducted by varying the amounts of $\mathrm{Ni}-\mathrm{Al}\left(\mathrm{NO}_{3}^{-}\right) \mathrm{LDH}$ from 100 to $300 \mathrm{mg}$. The test solution of $100 \mathrm{~mL}$ sample containing $100 \mu \mathrm{g}$ of mesalamine was passed through the column at optimum conditions. The results indicated that the quantitative recovery ( $>98 \%$ ) of mesalamine is in the range of 150-300 $\mathrm{mg}$. Therefore, $200 \mathrm{mg}$ of nanosorbent were used for further experiments.

\section{Sample volume and pre-concentration factor}

In order to explore the possibility of enriching low concentrations of analyte from large volume, the effect of sample volume on the recovery of mesalamine was investigated. In this case, 10, 25, 50, 100, 150 and $200 \mathrm{~mL}$ of sample solutions containing $100 \mu \mathrm{g}$ of mesalamine were processed according to the recommended procedure. Recovery of mesalamine was found to be quantitative when sample volume was chosen between the ranges of 10-100 mL. Above $100 \mathrm{~mL}$, the recovery decreased for the analyte. So, by analyzing $2.5 \mathrm{~mL}$ of the final solution after the pre-concentration of $100 \mathrm{~mL}$ of sample solution, an enrichment factor was found as 40 .

\section{Sorption capacity}

The capacity of the sorbent is an important factor that determines how much sorbent is required to quantitatively remove a specific amount of analyte from the solution, and given by milligram of analyte per gram of solid phase. The sorption capacity of the $\mathrm{Ni}-\mathrm{Al}\left(\mathrm{NO}_{3}^{-}\right) \mathrm{LDH}$ nanosorbent was obtained by the batch technique. For this process, $100 \mathrm{mg}$ of the sorbent were added to $50.0 \mathrm{~mL}$ of solution containing $100 \mathrm{mg} \mathrm{L}^{-1}$ of mesalamine and stirred for $60 \mathrm{~min}$ with magnetic stirrer and filtered through a filter paper. Enriched mesalamine in LDH nanoparticles was stripped with $5 \mathrm{~mL}$ of $3.0 \mathrm{~mol} \mathrm{~L}^{-1} \mathrm{NaOH}$ and the concentration of mesalamine was spectrofluorometrically determined after dilution. As a result, the capacity of $\mathrm{Ni}-\mathrm{Al}\left(\mathrm{NO}_{3}^{-}\right) \mathrm{LDH}$ for mesalamine was found to be $4.2 \mathrm{mg} \mathrm{g}^{-1}$.

Reusability of $\mathrm{Ni}-\mathrm{Al}\left(\mathrm{NO}_{3}^{-}\right) \mathrm{LDH}$ nanosorbent

The stability and regeneration potential of the column were also investigated. The column can be reused after regeneration with $2.0 \mathrm{~mL}$ of $3.0 \mathrm{~mol} \mathrm{~L}^{-1} \mathrm{NaOH}$ and $3.0 \mathrm{~mL}$ deionized water, and stable up to at least 200 adsorption-elution cycles without significant loss of uptake capacity. The results indicate that the $\mathrm{Ni}-\mathrm{Al}\left(\mathrm{NO}_{3}^{-}\right) \mathrm{LDH}$ nanosorbent is stable as well as no carryover of analyte during SPE procedure, showing good reusability.

\section{Study of interferences}

The effects of some coexisting ions and compounds on the adsorption of mesalamine on $\mathrm{Ni}-\mathrm{Al}\left(\mathrm{NO}_{3}^{-}\right) \mathrm{LDH}$ were investigated. In these experiments, different amounts of some interfering ions and compounds might exist in human blood serum and were added to the test solutions containing $10.0 \mu \mathrm{g} \mathrm{L}^{-1}$ of mesalamine and then, followed according to general procedure. The tolerance limit was considered if it resulted in a $\pm 5 \%$ variation in recovery of mesalamine. As can be seen in Table 1, most of the examined cations and anions did not interfere with the extraction and determination. The selectivity of the method was further evaluated. For this purpose, the emission spectra of human blood serum before and after loading on the column were constructed and compared with standard aqueous solution of mesalamine. It was found that although the initial solution of serum has a complicate spectrum, no variation is observed in the peak wavelengths of the emission spectra in extracted solution with respect to

Table 1. Tolerance limits of interfering ions in the determination of $10.0 \mu \mathrm{g} \mathrm{L}^{-1}$ of mesalamine

\begin{tabular}{lc}
\hline Coexisting ions & Interferent to analyte ratio \\
\hline $\mathrm{Na}^{+}, \mathrm{K}^{+}, \mathrm{Ca}^{2+}, \mathrm{Mg}^{2+}, \mathrm{NO}_{3}^{-}$ & $1000: 1$ \\
$\mathrm{IO}_{3}^{-}, \mathrm{I}^{-}$, epinephrine, salicylic acid & $100: 1$ \\
$\mathrm{CO}_{3}^{2-}, \mathrm{BrO}_{3}^{-}, \mathrm{Br}^{-}, \mathrm{CH}_{3} \mathrm{COO}^{-}$ & $80: 1$ \\
$\mathrm{SO}_{4}^{2-}, \mathrm{Cl}^{-}, \mathrm{F}^{-}, \mathrm{C}_{6} \mathrm{H}_{5} \mathrm{O}_{7}^{3-}$, aspirin, ascorbic acid & $50: 1$ \\
$\mathrm{H}_{2} \mathrm{PO}_{4}^{-}, \mathrm{HPO}_{4}^{2-}$ & $10: 1$ \\
\hline
\end{tabular}


those ones in standard aqueous solution. All these facts suggest that the $\mathrm{Ni}-\mathrm{Al}\left(\mathrm{NO}_{3}^{-}\right) \mathrm{LDH}$ nanosorbent has great potential for the selective extraction of mesalamine from complex matrices.

\section{Analytical performance}

Under the experimental conditions, a series of experiments was designed for obtaining linear range, precision, limit of detection (LOD) and enrichment factor. Table 2 shows the analytical characteristics of the method. The calibration graph was linear in the range of 0.1-45.0 $\mu \mathrm{g} \mathrm{L}{ }^{-1}$, with a correlation coefficient of 0.9949. The linear regression equation was $\mathrm{F}=19.04 \mathrm{C}_{(5-\mathrm{ASA})}+47.38$, where $\mathrm{F}$ is the fluorescence intensity and $\mathrm{C}_{(5-\mathrm{ASA})}$ is mesalamine concentration in $\mu \mathrm{g} \mathrm{L}^{-1}$. LOD of the proposed method, which was evaluated as the concentration corresponding to three times the standard deviation (3 SD) of six replicate measurements of blank solution using the pre-concentration method, was found to be $0.04 \mu \mathrm{g} \mathrm{L} \mathrm{L}^{-1}$ for the pre-concentration of $100 \mathrm{~mL}$ of sample solution. The relative standard deviation (RSD) resulting from the analysis of six replicates of $100 \mathrm{~mL}$ solutions containing $10.0 \mu \mathrm{g} \mathrm{L} \mathrm{L}^{-1}$ mesalamine was $2.05 \%$. As the amount of mesalamine in the sample solution was measured after a final volume of $2.5 \mathrm{~mL}$, the solution was concentrated by a factor of 40 .

Table 2. Analytical characteristics of the proposed method

\begin{tabular}{lc}
\hline Analytical parameters & \\
\hline Linear range / $\left(\mu \mathrm{g} \mathrm{L}^{-1}\right)$ & $0.1-45$ \\
Intercept & 47.38 \\
Slope & 19.04 \\
Limit of detection / $\left(\mu \mathrm{g} \mathrm{L}^{-1}\right)^{\mathrm{a}}$ & 0.04 \\
Correlation coefficient & 0.998 \\
Relative standard deviation & $2.05(10)$ \\
RSD / \% $\mathrm{n}=6^{\mathrm{b}}$ & \\
Enrichment factor & 40 \\
\hline
\end{tabular}

${ }^{a}$ Calculated as three times the standard deviation of the blank signal; ${ }^{b}$ value in parentheses is the mesalamine concentration $\left(\mu \mathrm{g} \mathrm{L}^{-1}\right)$ for which the RSD was obtained; ' enrichment factor calculated as the ratio between the volume of the aqueous phase and the final volume.

\section{Analysis of real samples}

To test the reliability of the proposed procedure, the method was employed to determine trace amounts of mesalamine in blood serum samples. In order to verify the accuracy of the established procedure, recovery experiments were also carried out by spiking samples with different amounts of mesalamine before any pretreatment. Table 3 shows the obtained results. As can be seen, recoveries between 96.00 and $99.00 \%$ were obtained, confirming the accuracy of the proposed method. There was no available certified reference material (CRM) of mesalamine to test the validity of the proposed method, but the results of the method were compared with results of a spectrophotometric method (Table 4). Applying the paired $t$-test, no significant difference at $95 \%$ confidence level was observed. It can be concluded that the proposed method is accurate and free from systematic errors.

Table 3. Determination of mesalamine in human blood serum samples ${ }^{\mathrm{a}}$ (results of recoveries of spiked sample analysis)

\begin{tabular}{lccc}
\hline $\begin{array}{l}\text { Sample } \\
\text { number }\end{array}$ & $\begin{array}{c}\text { Added 5-ASA } \\
\left(\mu \mathrm{g} \mathrm{mL}^{-1}\right)\end{array}$ & $\begin{array}{c}\text { Found 5-ASA } \\
\left(\mu \mathrm{g} \mathrm{mL}^{-1}\right)\end{array}$ & $\begin{array}{c}\text { Recovery / } \\
\%\end{array}$ \\
\hline 1 & - & $10.54 \pm 0.77$ & - \\
& 5.00 & $15.49 \pm 0.71$ & 99.00 \\
\hline 2 & 10.00 & $20.17 \pm 0.58$ & 96.30 \\
\hline 3 & - & $31.72 \pm 0.87$ & - \\
& 5.00 & $36.59 \pm 0.73$ & 97.35 \\
& 10.00 & $41.57 \pm 0.68$ & 98.50 \\
\hline 4 & - & $12.30 \pm 0.64$ & - \\
& 5.00 & $17.13 \pm 0.83$ & 96.50 \\
& 10.00 & $22.04 \pm 0.68$ & 97.40 \\
\hline & - & $5.24 \pm 0.94$ & - \\
& 5.00 & $10.15 \pm 0.83$ & 98.20 \\
& 10.00 & $14.84 \pm 0.72$ & 96.00 \\
\hline
\end{tabular}

abtained from the blood bank of the Shahid Madani Hospital, Azarshahr City, Iran; ${ }^{\mathrm{b}}$ mean of three experiments \pm standard deviation.

Table 4. Validation results of mesalamine analysis in human blood serum samples by spectrophotometric method compared with the proposed method under the optimum conditions ${ }^{\mathrm{a}}$

\begin{tabular}{lcc}
\hline \multirow{2}{*}{$\begin{array}{l}\text { Sample } \\
\text { number }\end{array}$} & \multicolumn{2}{c}{ Concentration found $^{\mathrm{b}} /\left(\mu \mathrm{g} \mathrm{mL}^{-1}\right)$} \\
\cline { 2 - 3 } & Spectrophotometric method & Proposed method \\
\hline 1 & $10.20 \pm 0.73$ & $10.54 \pm 0.77$ \\
3 & $29.84 \pm 4.70$ & $31.72 \pm 4.20$ \\
4 & $11.96 \pm 0.64$ & $12.30 \pm 0.64$ \\
\hline
\end{tabular}

${ }^{\text {aUtilized conditions: sample volume of } 100 \mathrm{~mL}, \mathrm{pH} 5 \text {, sample flow rate of }}$

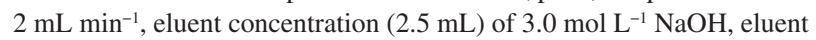
flow rate of $1.0 \mathrm{~mL} \mathrm{~min}^{-1}$ and amount of nanosorbent $200 \mathrm{mg}$; ${ }^{\text {bmean of }}$ three experiments \pm standard deviation.

\section{Comparison of the presented procedure with other methods}

A comparison of the presented method with other methods reported in the literature for mesalamine determination is shown in Table 5. As can be seen, the RSD and LOD of 
Table 5. Comparison of the proposed method with other determination methods

\begin{tabular}{lcccc}
\hline Determination method & Linear range / $\left(\mu \mathrm{g} \mathrm{L}^{-1}\right)$ & LOD / $\left.\mu \mathrm{g} \mathrm{L}^{-1}\right)$ & RSD / \% & Reference \\
\hline DPV & $300-5314$ & 124.9 & 1.35 & 2 \\
Spectrophotometry & $15-50$ & 580 & 0.4024 & 5 \\
Spectrophotometry & $2000-25000$ & $n . r^{\mathrm{c}}$ & $0.104-0.263$ & 6 \\
Spectrofluorimetry & $320-27600$ & 160 & 2.66 & 7 \\
Coulometry & $240-19200$ & $n . r^{\mathrm{c}}$ & 2 & 1.5 \\
HPLC & $1-700$ & 19 & 3.5 & 10 \\
HPLC-ESI-MS/MS & $50-4000$ & 15 & 2.05 & 16 \\
SPE-spectrofluorometry & $0.1-45$ & 0.04 & present work \\
\hline
\end{tabular}

${ }^{\mathrm{a} D P V}$ : differential pulse voltammetry; ${ }^{\mathrm{H} H P L C}$-ESI-MS: high performance liquid chromatography-electrospray ionization-mass spectrometry; ${ }^{\mathrm{c}}$ not reported.

the presented method are comparable or better than other reported methods. The coupling of novel $\mathrm{Ni}-\mathrm{Al}\left(\mathrm{NO}_{3}^{-}\right) \mathrm{LDH}$ nanosorbent for SPE procedure with spectrofluorometric detection exhibited excellent selectivity, repeatability and ease of operation. Thus, the presented method could be of great interest especially for mesalamine determination in routine analytical laboratories.

\section{Conclusions}

It can be concluded from the obtained results that nanostructured nickel-aluminum layered double hydroxide $\left(\mathrm{Ni}-\mathrm{Al}\left(\mathrm{NO}_{3}^{-}\right) \mathrm{LDH}\right)$ is an effective and suitable sorbent and can be used for separation and extraction of some acidic drugs from complex matrices. To the best of our knowledge, this is the first time that $\mathrm{Ni}-\mathrm{Al}\left(\mathrm{NO}_{3}^{-}\right) \mathrm{LDH}$ was used as packing material for the selective solid-phase extraction and pre-concentration of mesalamine. This methodology gives good accuracy, low limits of detection, excellent precision and high kinetic sorption on the target analyte, showing its potentiality in trace analysis in various samples with complicated matrix. On the other hand, nanometer-sized $\mathrm{Ni}-\mathrm{Al}\left(\mathrm{NO}_{3}^{-}\right) \mathrm{LDH}$ is a good choice for the separation and pre-concentration of acidic drugs from aqueous samples due to its low cost when compared to commercially available sorbents.

\section{Acknowledgment}

The financial support from the Research Council of Azarbaijan University of Tarbiat Moallem (AUTM, Iran) is gratefully acknowledged.

\section{References}

1. Mladenovska, K.; Raicki, R. S.; Janevik, E. I.; Ristoski, T.; Pavlova, M. J.; Kavrakovski, Z.; Dodov, M. G.; Goracinova, K.; Int. J. Pharm. 2007, 342, 124.
2. Nigović, B.; Šimunić, B.; J. Pharm. Biomed. Anal. 2003, 31, 169.

3. Nigovi, B.; Simuni, B.; Hocevar, S.; Electrochim. Acta 2009 , 54,5678 .

4. Lovric, S. K.; Nigovi, B.; J. Pharm. Biomed. Anal. 2004, 36, 81.

5. Sloka, S. N.; Gurupadayya, B. M.; Kumar, C. A.; Der. Pharma Chemica 2010, 2, 389.

6. Acharjya, S. K.; Sahu, A.; Das, S.; Sagar, P.; Annapurna, M. M.; J. Pharm. Educ. Res. 2010, 1, 63.

7. Cui, F. L.; Fan, J.; Li, W.; Fan, Y. C.; Hu, Z. D.; J. Pharm. Biomed. Anal. 2004, 34, 189.

8. Lianidou, E. S.; Ioannou, P. C.; Clin. Chem. 1996, 42, 1659.

9. Abdullin, I. F.; Chernysheva, N. N.; Budnikov, G. K.; J. Anal. Chem. 2002, 57, 856.

10. Nobilis, M.; Vybiralova, Z.; Sladkova, K.; Lisa, M.; Holcapek, M.; Kvetina, J.; J. Chromatogr., A 2006, 1119, 299.

11. Aguzzi, C.; Capra, P.; Bonferoni, C.; Cerezo, P.; Salcedo, I.; Sánchez, R.; Caramella, C.; Viseras, C.; Appl. Clay Sci. 2010, 50, 106.

12. Chungi, V. S.; Rekhi, G. S.; Shargel, L.; J. Pharm. Sci. 1989, $78,235$.

13. Hussain, F. N.; Ajjan, R. A.; Moustafa, M.; Anderson, J. C.; Riley, S. A.; J. Chromatogr., B: Anal. Technol. Biomed. Life Sci. 1998, 716, 257.

14. Bystrowska, B.; Nowak, J.; Brandys, J.; J. Pharm. Biomed. Anal. 2000, 22, 341.

15. Orioli, M.; Marinello, C.; Cozzi, R.; Piodi, L. P.; Carini, M.; J. Pharm. Biomed. Anal. 2004, 35, 1263.

16. Pastorini, E.; Locatelli, M.; Simoni, P.; Roda, G.; Roda, E.; Roda, A.; J. Chromatogr., B: Anal. Technol. Biomed. Life Sci. 2008, 872, 99.

17. Palumbo, G.; Bacchi, S.; Primavera, L.; Palumbo, P.; Carlucci, G.; Biomed. Chromatogr. 2005, 19, 350.

18. French, D. L.; Mauger, J. W.; Pharm. Res. 1993, 10, 1285.

19. Krishnan, T. R.; Ibraham, I.;J. Pharm. Biomed.Anal. 1994, $12,287$.

20. Tamayo, F. G.; Turiel, E.; Esteban, A. M.; J. Chromatogr., A 2007, 1152, 32. 
21. Braterman, P. S.; Xu, Z. P.; Yarberry, F. In Handbook of Layered Materials; Auerbach, S. M.; Carrado, K. A.; Dutta, P. K., eds.; Marcel Dekker, Inc.: New York, 2004, p. 373-474.

22. Cavani, F.; Trifiro, F.; Vaccari, A.; Catal. Today 1991, 11, 173.

23. Goh, K. H.; Lim, T. T.; Dong, Z.; Water Res. 2008, 42, 1343.

24. Béres, A.; Pálinkó, I.; Kiricsi, I.; Nagy, J. B.; Kiyozumi, Y.; Mizukami, F.; Appl. Catal., A 1999, 182, 237.

25. Nshuti, C. M.; Songtipya, P.; Manias, E.; Jimenez-Gasco, M. M.; Hossenlopp, J. M.; Wilkie, C. A.; Polymer 2009, 50, 3564.

26. Yina, H.; Cuia, L.; Aia, S.; Fana, H.; Zhub, L.; Electrochim. Acta 2010, 55, 603.

27. Ai, H.; Huang, X.; Zhu Z.; Liu, J.; Chi Q.; Li, Y.; Biosens. Bioelectron. 2008, 24, 1048.
28. Musumeci, A. W.; Mortimer, G. M.; Butler, M. K.; Xu, Z. P.; Appl. Clay Sci. 2010, 48, 271.

29. Gunawan, P.; Xu, R.; J. Phys. Chem. 2009, 113, 17206.

30. Kovanda, F.; Rojka, T.; Bezdicka, P.; Jiratova, K.; Obalova, L.; Pacultova, K.; Bastl, Z.; Grygar, T.; J. Solid State Chem. 2005, 182, 27.

31. Li, K. W.; Kumada, N.; Yonesaki, Y.; Takei, T.; Kinomura, N.; Wang, H.; Wang, C.; Mater. Chem. Phys. 2010, 121, 223.

32. Mas, V.; Dieuzeide, M. L.; Jobbágy, M.; Baronetti, G.; Amadeo, N.; Laborde, M.; Catal. Today 2008, 133, 319.

Submitted: March 23, 2011

Published online: January 24, 2012 